\title{
THE INTERPRETATION OF THE
} NEW TESTAMENT AS THE STUDY OF TEXTS AND CONTEXTS: HERMENEUTICS, IDENTITIES, COMMUNITIES ${ }^{1}$

\section{ABSTRACT}

The focus here is on texts, Pauline and texts invoked by Paul, and ever-present imperial "super"-texts. The latter also establishes the context, as the social setting of Paul's letters with their rhetorical use of Othering was the Roman Empire with its identity politics. The rhetorical power of Paul and his scriptural texts contributed to discursive formations, since a strong sense of being and identity was negotiated through these texts, even when admitting that such formations are always in process, mutating and reformatting. Construing notions of Others was a particularly important feature in defining boundaries, for generating insiders and outsiders in Pauline texts.

\section{INTRODUCTION: IMPORTANCE OF IDENTITY, THEN AND NOW}

The study of the New Testament is primarily a hermeneutical venture, a quest in interpreting and making sense of texts and contexts from antiquity. Teaching and researching the New Testament often involves a broader hermeneutical role and additional contexts, such as exploring the sense of ancient texts for modern contexts like faith communities. New

1 Edited version of an inaugural lecture, Stellenbosch University, 17 April 2012, printed here with permission of the University. It is presented in collegial dedication upon his retirement to the valuable contributions of scholar and friend Prof dr Hermie C van Zyl to New Testament studies in South Africa over many years.

Prof. Jeremy Punt, Faculty of Theology, Stellenbosch University. E-mail address: jpunt@sun.ac.za. 
Testament texts and contexts were in the past and today at times still are interpreted in various useful and interesting as well as obfuscating and even deplorable ways - in the academy, church and society. More to the point, sacred scriptures have always been involved in how religious communities identify themselves: a reciprocal movement of sacred texts informing communities and communities making sense of texts. The interplay between text, hermeneutics and communities, then, can be explained from the vantage point of identity understood as sense of self as well as identity formed in relation to otherness.

Framing identity in terms of other groups or people as "Others" or through "otherness" in the New Testament has seen much investigation recently. ${ }^{2}$ Paul's claims about otherness, of difference between various people and groups divided by various boundaries do not exclude the possibility of difference in substance. However, like identity, difference was no static entity. It was culturally encoded and rhetorically expressed with political and cultural implications. ${ }^{3}$ Otherness was often more illuminating of the boundaries desired by an author than the characteristics of the people in question. In Paul's letters in the New Testament it is his constant explicit appeals to and subtle intimations of the Scriptures of Israel that illustrate the interplay between texts, hermeneutics and communities, and its impact upon identity - such as when he appeals to Abraham in his letter to the Galatians, as argued below.

The burgeoning field of studies on identity (including ethnicity) in the New Testament has contributed to renewed interest in the nature of intersections between texts and contexts. This meeting of concern about hermeneutics and text, and communities and identity stimulates much research in New Testament studies. The impetus follows in the footsteps of a long, even if not always equally smooth, tradition of scholarship of studying biblical texts in their original context of the ancient, Mediterranean world.

\section{A MATTER OF CONTEXTS; CONTEXTS MATTER!}

Working on matters related to identity in the New Testament cannot be restricted to the literary study of texts because only in social locations do

2 A sample of recent material includes Buell (2005); Campbell (2008); Dunning (2009); Ehrensperger and Tucker (2010); Hodge (2007); Wills (2008); cf Spina (2009) for (mostly) the OT.

3 Categories and notions of otherness and difference are inherently unstable (cf. Dunning 2008:5) and while their deployment in NT texts is rhetorical, their connections to language and politics deserve attention. 
they have meaning. The background, social setting or location, or context ${ }^{4}$ has never been missing from New Testament studies, even if the scope and nature of its involvement has been somewhat of a mixed bag. ${ }^{5}$ In the very earliest stages of biblical interpretation, then still largely restricted to ecclesial frames, even the Antiochean school of the fourth century and still later the Medieval quadriga (four-fold scriptural interpretation) already made provision for literal interpretation of texts. However, the recognition of the text's historical setting in interpretation hardly affected their interpretation (Bray 1996:105-107; 147-157).

It was with the advent of the critical study of the Bible in the late $18^{\text {th }}$ century onwards, that the historical consciousness informing work on biblical interpretation since the sixteenth century was picked up and further elaborated. ${ }^{6}$ The dominance of the historical-critical method with its strong connection to the development of New Testament studies as such (Lategan 2004:140) soon set in. In the twentieth century socio-historical contexts of texts increasingly attracted attention and began to feature in biblical interpretation in a way and to an extent not seen before. ${ }^{7}$ With many biblical scholars moving away from the historical-critical method with its positivist moorings, ${ }^{8}$ new historiographical insight thinks differently about history and access to it, as it holds that historical memory is a dynamic, constructive and sense-making venture. ${ }^{9}$ In conjunction with the use of

4 These are some of the terms used to refer to the social location of the NT texts - my preference is for "social location", the rationale for which will soon become clear.

5 Thiselton (2006) provides a longer introduction and discussion of biblical hermeneutics but cf. also e.g. Blount (1995), Schüssler-Fiorenza (1999) and Segovia (2000) for various considerations of the state of the discussion.

6 Good examples of the radical turn taken by the encounter with history are found in Kümmel (1958:358-362), when both the authenticity of the texts and the validity of their claims were challenged (cf. Lategan 2004:138).

7 Not unlike, and probably not unrelated to larger epistemological and hermeneutical shifts in the world, as Diner explains in his essay on framing historical paradigms as "delayed modes of interpretation of historical processes that have preceded them" (Diner 2007:151). The age of memory has overrun the age of society, as much as the latter displaced the earlier "sematicization" of nation or state, which in turn was preceded by the premodern ancient régime (Diner 2007:149-163).

8 "The theological justification, or better still, the sanctification of the historicalcritical method by Käsemann, thus rests squarely on its perceived ability to guarantee closeness to (historical) reality (Wirklichkeitsnähe)" (Lategan 2004:140; cf. Martin 2008:3-9). Cf. Segovia (1995b:278-280).

9 "Memory could be described as the articulation of the past in the present" (Pollak 2009:296). Not only does social memory studies still lack an "orderly 
sociological, anthropological and related investigative frameworks among biblical scholars, historical concerns have started to assume a different role in biblical interpretation. ${ }^{10}$

The difference is twofold, both epistemological and methodological. As far as epistemology is concerned, there is a growing conviction that searching for "reality behind the text" is passé, partly because "reality" is the wrong word to use for what such searches can conceivably produce; partly because it is an exercise doomed to fail; and partly because the intended aim with the product (i.e. the sought after reality) is often problematic. The argument extends beyond the scope of this presentation but suffices it to hold here that reality is always construed, never objective or neutral, not found but constructed. ${ }^{11}$ The typical intent of historical-critical searches for the reality behind the text was (and is) situated in a controlling function, in historical-critical sanctioning or at least arbitration. ${ }^{12}$ The late twentieth century "linguistic turn" in New Testament studies unfortunately did not arrest altogether the exploitation of a text's social location, not even amidst fervent activity in textuality and literary representation (Lopez 2011:69). However, with the increasing recognition that literary texts are part of a larger "inseparable, relational web of residues and artifacts

center", it is used to include studies on oral and written myth expressed through religion and nationalism, mnemonic practices in specific social sites, the social recollection of habitual human activity, or its malleability and political use.

10 The resistance of New Testament scholars to admit to the sense-making role of historical work can be connected to theological reasons (textual validity depends on historical truth), scholarly work (recognition of the biblical texts' historicity, but reluctance to live up to the "linguistic turn"), and epistemological reasons (rationalistic and positivist legacy of historical-critical work as well as the perpetual fear of anachronism or the danger of "modernising" texts) (Lategan 2004:145-146). However, too much faith in the ability of texts to construe or portray its own world may ascribe such a strong agency to texts that it inhibits recognition of the ideological interests of interpreters.

11 Opposition to essentialist understanding does not imply the rejection of flesh and blood entities (as propagated by some, cf. Roth 2003). It points to the illusionary nature of sure categories (essentialism) and certain grounds (objectivity), i.e. to view social phenomena in terms of transhistorical essences, independent of conscious beings, refusing to admit that people determine the categorical structure of reality.

12 Often with theological justification, or as Lategan puts it, "sanctifying" the historical critical method since it was (is) believed to guarantee closeness to historical reality (Wirklichkeitsnähe), protecting Bible readers against both a sacrificium intellectus when the secular setting of the sacred disappears from view, and a docetic theology where Christ is mere metaphysical symbol (Lategan 2004:144, responding to Ernst Käsemann's work in particular). Cf. Segovia (1995:281-285). 
that hang together in ways that are not always easily comprehensible" (Lopez 2011:80), and as all of the above are embedded in various power constellations, the recent "political turn" (Stanley 2011:111) in Pauline studies is not difficult to understand (cf. below).

Methodologically, the different approach to historicity in dealing with the social setting of the New Testament is also telling. ${ }^{13}$ It is situated in a move away from "background" studies aimed at casting light on the otherness of the first-century context in various historical, social, political, economic and cultural ways. The focus has shifted to the enlistment of social locations in all their complexity as heuristic devices. ${ }^{14}$ More than serving an almost aesthetic function of situating the text, context as social location is invariably more concerned with providing a plausible interpretative framework for textual interpretation. Rather than invoking appreciation for the exotic, context as social location wants to map out the possible resonances of the text, permissible connotations and denotations of meaning, and illocutionary effects. Also, rather than the New Testament texts providing windows on the ancient world, the construction (not reconstruction!) of plausible social settings for ancient texts honours the notion that there is no uninterpreted reality (cf. Lategan 2004:145).

A different approach to history and historical enquiry, therefore, is in the offing and likely to be taken up increasingly by biblical scholars. ${ }^{15}$ While scepticism against historical criticism has been mounting, ${ }^{16}$ scholars have never disputed the importance of historical consciousness in biblical

13 The emphasis in historical criticism on methodological expertise had a number of salient weaknesses (Segovia 1995b:281-285). The dangers of an overreliance on a self-consuming "historical-critical method" are already evident in claims about its self-evident importance.

14 The material setting and social location of texts do not serve as either mere backdrop or evidence to prove the historicity of biblical texts and figures (cf. Lopez 2011:79).

15 Three important aspects of the study of historical narrative include: writing of history is always more and less than the past; historiography account for the present to which the past has led: it is thus a powerful instrument of community legitimation, identity formation and instruction; and, in history/writing, events acquire narrative form.

16 Particularly in theoretical sense, since historical-critical studies are amidst theoretical challenges still widely practiced (cf. Segovia 1995a:1-32). Cf also Bray (1996:480-481) on the analytic rather than synthetic nature of historical criticism; lacking a coherent system of thought; relying on inadequate data; and, its concern with texts factual accuracy. For arguments on the continuing value of historical criticism, even if in a new guise, cf. e.g. Barton (1998:9-20); Collins (2005); Fitzmeyer (2008). 
studies. Biblical scholars still show much affinity for history and its value, ${ }^{17}$ but for a new sense of historiography, ${ }^{18}$ what some have called a new historicism ${ }^{19}$ (cf. Henz-Piazza 2002). The languishing debate about texts as illuminating window on the ancient world or as self-reflecting mirror of contemporary readers' interests aside,$^{20}$ the construction of plausible social locations for texts is no optional extra in New Testament hermeneutics. What is needed so that concern for plausible historical settings does not mute out linguistic, structural and reception-historical aspects in hermeneutics? How to avoid attempts at control over meaning through claims on history? Employing historiographical insights which takes its assembled nature seriously shifts the focus away from texts providing access to some vaunted real reality and from contexts accorded either aesthetic or controlling functions. Rather, the focus falls on appreciating the constructed or re-membered nature of history, ${ }^{21}$ and on honouring the interrelationship between texts and contexts, that is, that texts construct contexts as much as texts are embedded in contexts. ${ }^{22}$

In the case of Paul, while at surface level addressing the matter of their new identity, at a deeper level his appropriation of a historical Jewish tradition for Jesus followers in Galatia, is indicative of the interplay between hermeneutics, texts, and communities in historical settings. Paul's letters with their rhetorical force was part of the earliest discursive and rhetorical formations of the early followers of Jesus which, as is clear also from

17 "And even where [in the study of religions and theology] texts remain of central concern there is new interest in the social and cultural conditions within which they were produced and in the concrete histories of their transmission and reception" (Davaney 2001:9).

18 Historiography has been described "as the written record of what is known of human lives and societies in the past and how historians have attempted to understand them" (Partner 2008:1; emphasis added).

19 "New Historicism is essentially a turn away from theory and a movement in the direction of culture, history, politics, society and institutions as the social contexts of the production of texts" (Carroll 1998b:52).

20 Extending the metaphor(s) the text can be studied as portrait, in its own right neither for access to the past nor as reflection of current readerly positions and interests (cf. Bray 1996).

21 From a literary perspective, "History is 'fictional', not in the sense of something false but in the sense of something produced in language" (Schüssler Fiorenza 1989:23).

22 Of course, such historiographical efforts are as much loaded with ideological interests and concerns as historical critical approaches have always been. The denial of interests is as useless as their eradication is impossible, and therefore requires transparency in approach and continuous cross-checks and balances between different methodologies and results. 
the variety of New Testament documents, gave rise to various social formations..$^{23}$ The two aspects of Paul's negotiation of identity in Galatians in focus here are his appropriation of a scriptural tradition about Abraham and Otherness claims which at times resembled imperial othering.

\section{PAUL, IDENTITY AND TEXTS IN AN IMPERIAL SETTING}

A re-evaluation of historiography in textual interpretation includes accounting for the Roman Empire's ubiquity in the time of the New Testament, and the imperial setting's impact on texts and hermeneutics, communities and identity. Refocused attention to the imperial setting is not only related to a different approach to history and social location, but also the result of a more rounded approach to Paul. In fact, research on identity has gained significant momentum in Pauline studies particularly since the advent of "new(er)" perspectives. These perspectives have opened up different ways of understanding Paul, shying away from individualistic, spiritualised interpretations by insisting on the importance of the social location of Paul and his communities.

Seminal work by Krister Stendahl (1963) and Ed P Sanders (notably 1977, cf. 1983) was taken up and expanded by various other scholars (in Pauline studies, notably JDG Dunn 1982) as the New Perspective on Paul. The NPP (re)affirmed the Jewishness of the New Testament setting and in the process identified influential typecasts steering the interpretation of these texts. But, notwithstanding the ground-shifting work of the NPP, lingering and often negative stereotypes and thinking about Second Temple Judaism have not altogether been eradicated, also not in theological discussions and ecclesial traditions. ${ }^{24}$ More recently, the current Radical New Perspective on Paul (Zetterholm, Nanos, Eisenbaum and others) has confronted New Testament scholarship with yet another

23 These formations "represent not the inexorable verweltlichung or development toward world-church, but the constant cycle of problematization, protest, reform. Its social power lies in what it provides in imagination and discursive formation" (Wimbush 1996:34).

24 Cf. Elliott on the NPP not going far enough and especially Dunn still subscribing to the Jews/Paul binary (Elliott 1994:55-90): moving from theological contrast (soteriology and role of faith and works [of the law/Torah]) to a socio-cultural contrast (circumcision, dietary laws and festival days/Sabbath as identity markers). Jews who had their soteriology wrong have become Jews whose intact soteriology did not preclude them from excluding others on basis of their lack of Jewish credential and customs. 
range of questions about their socio-cultural environment and the identity of Jews, Paul and Jesus followers in the first century. In short, renouncing a history of ideas approach that spiritualises a universal Paul and dissatisfied with monolithic theological explanations demonising Jews, new avenues of trying to make sense of Paul have become available. Among others, scholars (often) inspired by imperial studies or postcolonial approaches increasingly are pointing to the importance of reading Paul in the context of Roman imperial rhetoric - a strategy not without contention. But at least a certain familiarity with imperial institutions and customs among firstcentury people need to be acknowledged, as Deissmann ([1910]1995:341) admitted already long ago.

\subsection{Imperialist social locations}

Especially when the southern Roman province of Galatia ${ }^{25}$ forms the social location of this letter, the imperial context is important for understanding its othering-discourse as well as subtle hints. But, historical descriptions of the material or ideological resources of Empire have unnecessarily suffered from a narrowness of focus. The Roman Empire was a negotiated concept, which created the very world it inhabited (cf. Hardt \& Negri 2000:xv), which is not to deny its strong, variegated material presence. But first and foremost Empire was a construct, a concept, not a nation, and thus without boundaries, a regime that effectively encompassed virtually the entire civilised world. Empire's rule extended beyond the material and exercised its influence not only on human bodies but on human psychology as well. Negotiations with imperial ideology and imposition were neither one-dimensional, nor devoid of intersecting and mutually informing crisscrossing lines between empire and subjects, nor oblivious to imperial ruboff amidst resistance against it (cf. Punt 2012).

A theme rather neglected until now, ${ }^{26}$ namely the deliberate or unconscious framing of a group's identity in contradistinction with imperial influence and impact (cf. Martin \& Barnes 2003:11), is important for our discussion. What did it entail for his sense of identity that Paul shared

25 Amid a larger and on-going debate, the position that the letter was directed to a community located in the Roman province of Galatia, in the south of Asia Minor rather than in the northern territory on the subcontinent is assumed (cf Fiensy 2004:48-50; Scott 1994).

26 "Reimagining Paul and his communities in his Roman imperial context through the postcolonial optic of hybridity is not about Paul or his Roman imperial context. Critical reimagination is about us and our desires for particular relationships with the ancient, contemporary, and future worlds" (Lopez 2011:94). 
the rhetorical and material world of the Roman Empire? When it comes to identity, it meant inhabiting a Roman-defined world which was blatantly suspicious of both western barbarians and eastern intemperates and effeminates (Lopez 2011:81), given the Romans' introspective sense of identity and their othering of peoples based on ideological reasons rather than historical "reality". ${ }^{27}$ First-century stereotyping as a particular instance of othering was not about the language of simple description and certainly not about accurate profiles of people, of other people, but rather about identity politics: marking out identity of self and others, reinforcing the self through denigrating the other. ${ }^{28}$ As Smith (1985:47) argued,

the real urgency of a 'theory of the other'... is called forth not by the requirement to place the 'other', but rather to situate ourselves.

Even stereotyping, privileged in imperial ideology, was primarily about defining the self through others. ${ }^{29}$

When Paul with little-concealed irritation referred to the letter recipients as "foolish Galatians" (Gal 3:1), he was invoking derogatory categories well-known at the time. With the letter directed to a community located in the Roman province of Galatia this would have served as an ethnic slur. For the inhabitants of a Roman province to be addressed as "Galatians" and "foolish" on top of that would be a grave insult. As an ethnic insult it suggested connotations with the descendants of the rather infamous Celtic people of the North, the imperial outsiders. More than ethnicity was involved, however, as at the time an accusation of foolishness was a gendered insult incurring downward slippage (Bassler 2007:45), with Galatian men assigned a stock trait ascribed to women. Used in a social setting where the Roman concept of "idiotic" or "foolish" dominated, Paul's remark framed his relationship with the Galatian congregation in terms reminiscent of empire. Identity was configured contextually as it only makes sense in social locations.

27 The Roman Empire gave a special ring to Foucault's remark that "the otherness of the Other...is by definition nothing in itself, but simply all we project onto it, the repository of our desires" (Carusi 1991:102).

28 Thus, accusations levelled by some Roman authors against the early Christians, such as ritualistic infanticide and cannibalism, "may be understood as entirely believable to his audience - not because the accusation was thought to be 'true' but because it efficiently expressed a collective distaste for the characteristic Christian refusal to participate in the common culture of city and empire" (Knust 2006:7).

29 "It is the prior understanding of the other as a dangerous threat to society that leads ancient authors, whether in history or fiction, to draw on a common stockpile of typical anti-societal actions" (Harland 2007:74). 


\subsection{Involvement of texts and identity}

By the first century texts in various forms have become an important mechanism in generating, formatting and disavowing (in short, negotiating) identity. The Roman imperial influence and its saturation of the material and ideological world with scripts, written and oral (cf. Lopez 2008) played no small part in the contribution of inscribed discourse to identity maintenance..$^{30}$ The relationship between narrative and memory is strong ${ }^{31}$ and characterised by immense diversity and variability, mediated by art and various forms of "narrative" - putting history into narrative frames (Pollak 2009:297). In his Res Gestae with its inscribed text spread over the ancient world Augustus rewrites history in name of Empire, reformatting events of the past to claim legitimacy for Roman imperial rule and celebrate its power. Literary design was linked intricately with political, socio-cultural and religious connotations and contexts.

Nevertheless, the ways in which people, also in the first century CE, constructed, devised and reformatted their and others' identity were multiple and diverse. Cultural, religious, (quasi-)political and various other concerns time and again came into play. Notwithstanding the oral environment, identity was nevertheless negotiated also through the use of texts and authoritative texts in particular. ${ }^{32}$ And once one moves beyond the stock in trade simplicity and mistake of viewing the New Testament documents as "Christian" documents aimed at putting down "the Jews" as the ultimate Others (e.g. Wills 2008:1, 167-193) in order to accommodate "the gentiles", a whole new world of identity and the sophisticated but complex and ambiguous ways in which it was plotted, opens up.

Paul recycled the Abraham narrative to establish boundaries between the followers of Jesus and those outside the group, even those sharing the same tradition, and to redefine the in-group. In Gal 4:21-5:1 Paul

30 "The threefold dialogue of memory with narrative design, socio-cultural mindset and socio-political interest, in itself infused by mindsets and ideals, continues throughout the generations in ever-changing contexts, as long as memory lasts" (Pollak 2009:298).

31 "...history relates to factuality and to actual situations, processes and events sequences in the past, whereas memory implies set of mind, value judgment, and, more than that, one's attitude to the past thus evoked" (Pollak 2009:296).

32 "On the one hand, then, narrative, whether in prose or in poetry, is the main channel for the performance of memory. On the other hand, the image of the past is profoundly affected by narrative. If history is a formless interplay and endless succession of occurrences, narrative imposes order and plot, and turns incidents into motifs that serve to build and to concretize the plot" (Pollak 2009:298). 
weaved together a secondary narrative of Abraham in which the status of the women assumes vital importance. Slavery has now become not only the criterion for difference but also for alignment of Jews and those following Jesus on the one hand, and all other Jews on the other hand. The Abraham narrative is basic to Paul's othering of another group that caused him much anguish (cf. Gal 5:12; possibly also Gal 1:8-9). ${ }^{33}$ With the question as to their own identity wide open, those Paul identified as his distracters appear to have held a different opinion from his regarding criteria and nature of Jesus-followers. It is probably the close proximity of Paul and his distracters, and the similarity in many respects between them (cf. Smith 1985:46-47) that contributed to Paul's agitated overreaction in Galatians, ${ }^{34}$ and which put his own boundaries to the test.

\subsection{Constructing / deconstructing identity in Galatians: Paul as Other?}

Paul's strategy of defining insiders and outsiders involved the use of the Scriptures of Israel. His appropriation of the Abraham narrative for Gentile believers adhered to the prevalent tactic of recycling traditions of others for the own group. But the role of othering in first-century identity politics begs caution. Not a time characterised by individualism, first century Mediterranean people derived their identity, which included their sense of being and belonging, from the groups they considered themselves part of. The plural is instructive. Amidst a confusing array of available affiliations, people in antiquity belonged to more than one group and groups existed for various purposes. The ancients' notion of identity was more nuanced than a simple or one-sided identity politics construed in opposition to real or imagined Others (Wills 2008:1-5). Otherness was not denied and

33 The Other is often constructed in situations of conflict, which can be described by a number of criteria ("laws"): conflict with external opponents serves to strengthen boundaries; it reinforces group structures; conflict is raised by the proximity of the opponents; conflict binds opponents together; and conflict contributes to a unitary view of opponents (Wills 2008:9-10)

34 Opinions differ about the origin and identity of those Paul identified as his opponents in Galatia, and even the terms with which they should be referred to: "judaizers", "opponents", "agitators" or "troublemakers", etc. Many terms for semantic, ideological and historical reasons and e.g. Nanos prefers "influencers (Nanos 2000:151). It has been suggested that they were emissaries from Antioch or Jerusalem who were tracking Paul since he left Antioch (Wan 2007:257-258), raising the question whether they were the same group elsewhere referred to as well, cf. Phil 3:2 (dogs, doers of evil deeds); 2 Cor 11:5, 12:11 (superapostles); or 2 Cor 11:15 (ministers of Satan)? Cf. also various contributions in Porter (2005); Söding (1991:205-323). 
at times emphasised, yet ancient societies often mounted their historical memories on a past borrowed from others. Past traditions were recycled when groups associated them with the traditions of others (Gruen 2011:34).$^{35}$ The appropriation, then, of the Other was not simply through creating or using existing contrasts. Others and their traditions were challenged, vilified, and denied but also taken up and retooled. ${ }^{36}$ This ambivalence is best seen in self-(ac)claimed otherness.

Already in Paul's letters traces of the trend towards self-styled alterity are present, which would in formative Christianity become prominent. In Galatians Paul's own identity was characterised by otherness at different levels, or at least the realisation of sliding towards the boundary of otherness. On the one hand his status as self-proclaimed apostle to the Gentiles (e.g. 2:2,7) did not mean relinquishing his Jewish identity (2:15), while on the other hand Paul's mission brought about his presence in alien territory. His close proximity to otherness in Galatians took its toll on Paul who now also appears as Other (Eisenbaum 2000:145). ${ }^{37}$ Regardless of Paul's implicit (e g Gal 3:6-9) and explicit (Gal 4:28) claims of sharing in Abraham's legacy, his letter to the Galatians indicates his concern of being side-lined from that legacy and accompanying traditions and identity: to remain within the "Israel of God" (Gal 6:12-16).

In Galatians Paul directs his audience's focus to the "Jerusalem above" (Gal 4:26). The Jerusalem above is the focal interest rather than "present Jerusalem". As "mother" it is also the explanation of the origin of

35 Ancient descriptions of Egyptians, Gauls, and Jews by Herodotus, Caesar, Tacitus and others did not rest on stereotypes or simplistic categories. Aeschylus's play Persae notwithstanding it portraying, Persians as national enemies despised by the gods whose defeat gratified the Athenian audience, does not tout Hellenic superiority versus barbarians. So also Herodotus' depiction of the Persians is multi-layered and restrained, and Xenophon's Cyropaedia presented the Iranian king as a model ruler. Herodotus is more interested in the connections between Greeks and Egyptians than in distance between them. The same holds true for Rome's impressions of her enemies. In the Germania, "Tacitus neither branded the German as 'Other' nor propped him up as inspired primitive to contrast with the degenerate Roman" (Gruen 2011:178). Such examples are multiplied in Gruen's work.

36 This does not imply, of course, that the Other was unimportant to ancient identity constructions and negotiations, as the Other remained an important if not always explicit or direct reference point.

37 Cf. also Dunning (2009). Taking up an outsider identity in Paul is complex, since the Otherness that he proclaims for believers resides in difference from this world as well as difference in certain customs and traditions (some of which even he shared) among the faithful. 
Jesus followers and their measure of orientation. Paul's insistence on the heavenly Jerusalem as yardstick of early Christian identity is embedded in his reappropriation of the Abraham narratives, as much as Abraham was the paradigmatic resident alien in the Hebrew Bible (e.g. Gen 23:4). Selfothering or assuming alterity in the form of the alien topos in theological discourse has often proved valuable, both for assisting Christians in articulating a counter-cultural stance as well as promoting a concomitant way of life. But claiming or celebrating otherness ${ }^{38}$ has a dangerous undercurrent in that the rhetoric of alien status can produce an unreflexive rigidity. ${ }^{39}$

Once one agrees that the New Testament documents, and the Bible as a whole, were constructed at some stage, and that perceptions of identity, of who or what constitutes "we" and "Other", were foundational to such constructive energies, the link between the formation and evolution of our biblical texts and constantly changing constructions of identity (cf. Wills 2008:3) is evident from the outset. ${ }^{40}$

38 Pointing to the early Jesus followers' celebration of difference through the paroikos (resident alien), xenos (stranger or foreigner), parepidēmos (sojourner) and politeia (citizenship) is remarkable in the face of universal claims (e.g. Mt 28:18-20; Ac 1:8, etc) but not sufficient given the fluidity of difference which needs to be unpacked (cf. Dunning 2009:1-3).

39 The danger manifests in a threefold way. One, claims to alien status can obscure the ways in which Christians have indeed made the world in which they live their own. It can, two, become a shield to avoid self-criticism, since their identity claims rely on the beliefs and behaviours which make them distinct from social conventions and sustain their claims to marginal or counter-cultural status. And finally the alien trope can also reinforce a sectarian mentality that may allow contact with other marginalised groups, but reinforces the distance from most other groups and even shuns the alterity of all others (Dunning 2009:113-116). Moreover, "Acts of identity formation are themselves acts of violence" (Schwarz 1997:5). Similarity in terms of identity or sameness also implies difference, which the constructing of self always invokes, and which construes the others as outsiders (cf. Lieu 2004:15).

40 As scholars and theorists like Edward Said pointed out in his Orientalism, the Bible was not left aside when it came to the construction of Otherness in the Western Empire's colonies. Maybe New Testament scholars in South Africa would want to align themselves with Perkins (2009:1) who introduces her work as that of a memorialist, "looking back at a historical moment with similarities to our own", rather than as a historian in a historiography genre tending "to generate narratives that point toward a meaningful future"? 


\section{CONCLUSION: NEW TESTAMENT TEXTS, CONTEXTS AND IDENTITY}

New Testament studies investigate biblical and other contemporary documents. These texts are studied along with the era or context in which they found their origins given the indissoluble link between text and context. Not the study of texts in context in the sense of searching for reality behind or through texts; but the study of texts and contexts in the sense of situating our interpretation within plausible constructions of the ancient world - well aware that context is constructed, and subject to interpretation as much as texts are subject to interpretation.

There are probably few, if any, collections of texts with whom so many people over so many centuries have interacted in the construction of their identity, their sense of being, and also their "Others" including their enemies. This may not have been happening at all times consciously. Also where the Scriptures inform their habitus, Bourdieu's remarks about agents' involvement in more than what they may be aware of, rings true:

It is because agents never know completely what they are doing that what they do has more sense than they know (Bourdieu 1990:69).

The past and on-going influence of the Bible in shaping modern constructions of the Other in our country and in various parts of the world, ${ }^{41}$ in various spheres of life, means that the study of texts and contexts, of interpreting communities and inscribed memories is vital both for understanding the New Testament and for people's lives today.

\section{BIBLIOGRAPHY}

BARTON, J.

1998. Historical-critical approaches. In J. Barton (ed.). The Cambridge companion to biblical interpretation. Cambridge: Cambridge University Press. Blount, BK. 1995. Cultural interpretation: Reorientating New Testament Criticism. (Minneapolis: Fortress), pp. 9-20.

BASSLER, J.M.

2007. Navigating Paul. An introduction to key theological concepts. Louisville, London: Westminster John Knox.

41 Wills boldly claims, "The Bible, directly or indirectly, defines identity for most of the people in the world" (Wills 2008:2). And of course, it should not escape the attention of New Testament scholars that the Bible itself is the result of a long process of defining self and Others. 
Bourdieu, P.

1990. The logic of practice. Stanford: University of Stanford Press.

BLOUNT, B.K.

1995. Cultural interpretation: Reorientating New Testament criticism. Minneapolis: Fortress.

BrAY, G.

1996. Biblical interpretation: Past and present. Downers Grove: InterVarsity.

BUELL, D.K.

2001. Rethinking the Relevance of Race for Early Christian Self-Definition. Harvard Theological Review 94(4):449-76.

2005. Why This New Race? Ethnic Reasoning in Early Christianity. New York: Columbia University Press.

Campbell, W.S.

2008. Paul and the Creation of Christian Identity. T \& T Clark Biblical Studies. London: T \& T Clark.

CARRoll, R.P.

1998. Poststructuralist approaches. New historicism and postmodernism. In J. Barton (ed.) The Cambridge companion to Biblical interpretation. Cambridge companions to religion. Cambridge: Cambridge University Press), pp.50-66.

Carusi, A.

1991. Post, post and post. Or, where is South African literature in all this? In I. Adam \& H. Tiffin (eds.). Past the last post: Theorizing post-colonialism and postmodernism. (New York: Harvester Wheatsheaf), pp.95-108.

Coluins, J.J.

2005. The Bible after Babel. Historical criticism in a postmodern age. Grand Rapids: Eerdmans.

DAVANEY, S.G.

2001. Theology and the turn to cultural analysis. In . D. Brown, S.G. Davaney \& $\mathrm{K}$. Tanner (eds.). Converging on culture. Theologians in dialogue with cultural analysis and criticism. AAR Reflection and theory in the study of religion series. (Oxford, New York: Oxford University Press), pp.3-16.

Deissmann, G.A.

1995 [1910]. Light from the Ancient East: The New Testament illustrated by recently discovered texts of the Greco-Roman world. 4th ed., trans. LRM Strachan. Peabody: Hendrickson.

DINER, D. 2007. From society to mmory: Reflections on a pradigm shift. In . D. Mendels (ed.). On memory. An interdisciplinary approach. (Oxford: Peter Lang), pp.149-63.

DunN, J.D.G.

1982. The new perspective on Paul. Bulletin of John Rylands Library 65:95-122. 
DUNNING, B.H.

2009. Aliens and sojourners. Self as other in early Christianity. Divinations: Rereading late ancient religion. Philadelphia: University of Pennsylvania Press.

Ehrensperger, K. \& TuCKeR, J.B. Eds.

2010. Reading Paul in context: Exploration in identity formation. Essays in honour of William S Campbell. Library of New Testament Studies, vol. 428. London: T\&T Clark / Continuum.

Eisenbaum, P.

2000. Paul as the New Abraham. In R.A. Horsley (ed.). Paul and politics. Ekklesia, Israel, Imperium, Interpretation. Essays inhHonor of Krister Stendahl. (Harrisville: Trinity Press International), pp.130-145.

ELLIOTT, N.

1994. Liberating Paul. The justice of God and the politics of the Apostle. The Bible \& Liberation. Maryknoll: Orbis.

FiENSY, D.

2004. The Roman Empire and Asia Minor. In S. McKnight \& G.R. Osborne (eds.). The face of New Testament studies. A survey of recent research. (Grand Rapids: Baker Academic), pp.36-56.

FITZMYER, J.A, SJ.

2008. The interpretation of Scripture. In defense of the historical-critical method. Mahwah: Paulist.

Gruen, E.S.

2011. Rethinking the other in antiquity. Martin Classical Lectures. Princeton: Princeton University Press.

Hardt, M. \& Negri, A..

2000. Empire. Cambridge, London: Harvard University Press.

Harland, P.A.

2007. "These people are...men eaters": Banquets of the anti-associations and perceptions of minority cultural groups. In Z.A. Crook \& P.A. Harland (eds.). Identity and interaction in the ancient mediterranean. Jews, Christians and Others. Essays in honour of Stephen G Wilson. New Testament Monographs. (Sheffield: Sheffield Phoenix), pp.56-75.

Hens-Piazza, G.

2002. The new historicism. Guides to Biblical Scholarship: Old Testament Series. Minneapolis: Fortress.

Hodge, C.J.

2007. If sons, then heirs. A study of kinship and ethnicity in the letters of Paul. Oxford, New York: Oxford University Press. 
KIRK, A.

2005. Social and cultural memory. In A. Kirk \& T. Thatcher (eds.) Memory, tradition, and text. Uses of the past in Early Christianity. Semeia Studies. (Atlanta: SBL), pp.1-24.

KNUST, J.W.

2006. Abandoned to lust. Sexual slander and ancient Christianity. Gender, theory, and religion. New York: Columbia University Press.

KüMmeL, W.G.

1958. Das Neue Testament, Geschichte der Erforschung seiner Probleme. Freiburg. Karl Alber.

LATEGAN, B.C.

2004. History and reality in the interpretation of Biblical texts. In J. Schröter \& A. Eddelbüttel (hrsg.). Konstruktion von Wirklichkeit: Beiträge aus geschichtstheoretischer, philosophischer und theologischer Perspektive. Theologische Bibliothek Töpelmann, vol. 127. (Berlin, New York: Walter de Gruyter), pp.135-152 .

LIEU, J.M.

2004. Christian identity in the Jewish and Graeco-Roman world. Oxford: Oxford University Press.

LOPEZ, D.C.

2008. Apostle to the conquered. Reimagining Paul's Mission. Paul in critical contexts. Minneapolis: Fortress.

2011. Visualizing significant otherness. Reimagining Pauline studies through hybrid lenses. In C.D. Stanley (ed.). The colonized Apostle. Paul through postcolonial eyes. Paul in Critical Contexts. (Minneapolis: Fortress), pp.74-94.

MARTIN, D.B.

2008. Pedagogy of the Bible: An Analysis and Proposal. Louisville: WJK.

MARTIN, J.M.\& BARNES, L.L.

2003. Introduction: Religion and Empire. JAAR 71(1):3-12.

Mattingly, D.J.

2011. Imperialism, power, and identity: Experiencing the Roman Empire (Miriam $S$ Balmuth Lectures in Ancient History and Archaeology). Princeton: Princeton University Press.

Nanos, M.

2000. The Inter- and Intra-Jewish Political Context of Paul's Letter to the Galatians. In R.A. Horsley (ed.) Paul and Politics. Ekklesia, Israel, Imperium, Interpretation. Essays in Honor of Krister Stendahl. (Harrisville: Trinity Press International), pp.146-159. 
PARTNer, N.F. 2008. Historiography (Concordia University, Wisconsin). [Online.] http://www. cuw.edu/Academics/programs/history/historiography (Retrieved 13 February 2008).

Perkins, J. 2009. Roman imperial identities in the early Christian era. Routledge Monographs in Classical Studies. London: Routledge.

Pollack, F.

2009. Afterword:Perspectives in retrospect. In A. Brenner \& F.H. Pollak (eds.) Performing memory in biblical narrative and beyond. The Bible in the modern world, vol 25; Amsterdam Studies in the Bible and Religion, vol 3. (Sheffield: Sheffield Phoenix), pp. 296-299.

Porter, S. E. (ED)

2005. Paul and his opponents. Pauline Studies2 Leiden, Boston: Brill.

Punt, J.

2012. Empire and New Testament texts: Theorising the imperial, in subversion and attraction. HTS Teologiese Studies/ Theological Studies 68(1), Art. \#1182, 11 pages. http://dx.doi.org/10.4102/hts. v68i1.1182

REVELL, L.

2009. Roman imperialism and local identities. Cambridge: Cambridge University Press.

Rотн, J.K.

2003. Response: Constructing and deconstructing empires. Journal of the American Academy of Religion 71(1):121-8.

SANDERS, E.P.

1977. Paul and Palestinian Judaism: A comparison of patterns of religion. Philadelphia / London: Fortress Press / SCM Press.

1983. Paul, the law, and the Jewish people. Philadelphia: Fortress Press.

SchWARTZ, R.M.

1997. The curse of Cain. The violent legacy of monotheism. Chicago \& London: University of Chicago Press.

SchüSSLER Fiorenza, E.

1989. Text and reality - Reality as text: The problem of a feminist historical and social reconstruction based on texts. Studia Theologica 43(1):19-34.

1999. Rhetoric and ethic. The politics of Biblical studies. Minneapolis: Fortress.

ScotT, J.M.

1995. Paul and the nations: The Old Testament and Jewish background for Paul's mission to the nations with special reference to the destination of Galatians. WUNT 84. Tübingen: Mohr Siebeck. 
Segovia, F.F.

1995a. "And they began to speak in other tongues": Competing modes of discourse in contemporary Biblical criticism. In F.F. Segovia \& M.A. Tolbert (eds.). Reading from this place. Vol. 1: Social location and Biblical interpretation in the United State. (Minneapolis: Fortress), pp. 1-32.

1995b. The text as other: Towards a hispanic American hermeneutic. In D. SmithChristopher (ed.). Text \& experience. Towards a cultural exegesis of the Bible. Biblical Seminar, vol. 35. (Sheffield: Sheffield Academic Press), pp. 276-298.

2000. Decolonizing Biblical studies: $A$ view from the margins. Maryknoll: Orbis.

SMITH, J.Z.

1985. What a difference a difference Makes. In J. Neusner \& E.S. Frerichs (eds.). "To see ourselves as others see us". Christians, Jews, "others" in late antiquity. (Scholars Press Studies in the Humanities. Chico: Scholars ), pp. 3-48.

SöDING, T.

1991. Die Gegner Des Apostels Paulus in Galatien. Beobachtungen zu ihrer Evangeliumsverkündiging und Ihrem Konflikt mit Paulus. Münchener Theologische Zeitschrift 42(4):305-23.

SPINA, F.A.

2005. The faith of the outsider. Exclusion and Inclusion in the Biblical story. Grand Rapids: Eerdmans.

Stanley, C.D.

2011. Paul the ethnic hybrid? Postcolonial perspectives on Paul's ethnic categorizations. In C.D. Stanley (ed.). The colonized Apostle. Paul through postcolonial eyes. Paul in criticalcContexts. (Minneapolis: Fortress), pp.110-126.

STENDAHL, K.

1963. The apostle Paul and the introspective conscience of the West. Harvard Theological Review 56:199-215.

Thiselton, A.C.

2006. Thiselton on hermeneutics: Collected works with new essays. Grand Rapids: Eerdmans.

WAN, S.

2007. The Letter to the Galatians. In F.F. Segovia \& R.S. Sugirtharajah (eds.). A postcolonial commentary on the New Testament writings. The Bible and Postcolonialis. (New York: T \& T Clark), pp.246-264.

WILLS, L.M.

2008. Not God's People: Insiders and outsiders in the Biblical world. Religion in the Modern World. Lanham: Rowman \& Littlefield.

Wimbush, V.L.

1996. “... Not of this world...": Early Christianities as rhetorical and social formation. In E. Castelli \& H. Taussig (eds.). Reimagining Christian origins: $A$ 
colloquium honoring Burton Mac. (Valley Forge: Trinity Press International), pp.23-36.

ZetTERHOLM, M.

2010. Jews, Christians, and Gentiles: Rethinking the categorization within the early Jesus movement. In K. Ehrensperger \& J.B. Tucker (eds.), Reading Paul in context: Exploration in identity formation. Essays in honour of William $S$ Campbell. Library of New Testament Studies, vol. 428. (London: T\&T Clark / Continuum), pp.242-254 .

$\begin{array}{ll}\text { Keywords } & \text { Trefwoorde } \\ \text { Social location } & \text { Sosiale ligging } \\ \text { Identity } & \text { Identiteit } \\ \text { Memory } & \text { Geheue } \\ \text { Empire } & \text { Wêreldryk } \\ \text { Galatians } & \text { Galasiërs }\end{array}$

